\title{
Ewelina Woźniak-Czech
}

\section{Literackie inscenizacje Georges'a Pereca}

\begin{abstract}
Woźniak-Czech Ewelina, Literackie inscenizacje Georges'a Pereca [Georges Perec's literary staging]. „Przestrzenie Teorii” 27. Poznań 2017, Adam Mickiewicz University Press, pp. 227-244. ISSN 1644-6763. DOI 10.14746/pt.2017.27.16.

The purpose of this sketch to present Georges Perec's work in the context of drama. As Perec wrote just one play for the theater, it's hard to call him a dramatist. However, it is easy to see that all the literary tricks he uses in his works are a part of a well-thought-out game. The author of Life a User's Manual employs and interweaves various literary conventions, prompts dialogue between his own works and draws the reader into the very center of his tricks, nuances and simulations. Perec's writing could be deemed a pure act of dramatization, where the author himself, to some extent, takes on the role of director, making his audience not so much the recipients of his texts but the actors performing them.
\end{abstract}

Przez całe życie pisze się jedna ksią̇̇kę, choć czasem się wydaje, $\dot{z}$ e jest inna, nowa, tak naprawde ma poczatek $w$ poprzedniej, z której wyrasta, ale idzie jednak dalej swoja droga ${ }^{1}$.

Nie moge sobie wyobrazić jakiegoś innego życia, w którym każdego dnia nie spędzałbym kilku godzin piszqc. [...] i na co moge mieć nadzieje w zwiazku z czytelnikami i tymi, którzy będa pisać po mnie, że zajmę miejsce jednego z tych kawatków uktadanki $i$ otworzę drogę komuś, kto na nowo będzie pisat po mojej śmierci ${ }^{2}$.

W twórczości jednego z najbardziej znanych członków „Warsztatu Literatury Potencjalnej” $\left(\mathrm{OuLiPo}^{3}\right)$ dorobek dramatopisarski wydaje się nader skromny. Ogranicza się do zaledwie dwóch utworów, wydanych w 1981 roku (tuż przed śmiercią Georges'a Pereca) w tomie Théâtre I (Teatr I, wydanie polskie w 2010 r.): powstałego na podstawie eksperymentalnej powieści L'Art et la manière d'aborder son chef de service pour lui demander une augmentation z 1968 r. (O sztuce oraz sposobach

${ }^{1}$ A. Krajewska, Dramatyczna teoria literatury. Zarys problematyki, Poznań 2009, s. 8.

2 G. Perec, K. Mortley, Robienie fikcji (rozmowa), przeł. A. Sosnowski, „Literatura na Świecie" 1995, nr 11-12, s. 172-173.

3 „Ouvroir de la Litterature Potentielle” to eksperymentalna grupa pisarzy i matematyków założona w 1960 r. przez Raymonda Queneau i François Le Lionnaisa. Ich celem było stworzenie nowej, abstrakcyjnej i całkowicie sztucznej literatury, która powstawałaby zgodnie z dobrowolnie narzucanymi rygorami, właściwymi funkcjom matematycznym (zob. A. Wasilewska, Od tłumacza, [w:] I. Calvino, Jeśli zimowa noca podróżny..., Warszawa 1989, s. 263; Eadem, Oulipo, czyli recepta na życie bez końca; <http://www.lokatormedia. pl/oulipo-nie-konczy-nawet-smierc-anna-wasilewska> (dostęp: 21.04.2017). 
usidlenia kierownika działu $w$ celu upomnienia się o podwyżke, wydanie polskie w 2011 r.) scenariusza słuchowiska radiowego L'Augmentation ou Comment, quelles que soient les conditions sanitaires, psychologiques, climatiques, économiques ou autres, mettre le maximum de chance de son côté en demandant à votre chef de service un réajustement de votre salaire (Podwyżka, czyli jak, bez względu na warunki sanitarne, psychologiczne, klimatyczne, ekonomiczne i inne, uzyskać jak największe szanse, zwracajac się do kierownika działu o podwyższenie płacy, pierwsze wydanie w języku polskim ukazało się na łamach „Dialogu” w 1985 r. ${ }^{4}$ ) oraz jedynej w dorobku pisarza sztuki La Poche Parmentier (Schowek Parmentier, wydanie polskie w 2010 r.). Perec pisał również teksty do kilku słuchowisk dla niemieckich rozgłośni radiowych, niestety, istnieją one jedynie $\mathrm{w}$ eterze i prawdopodobnie nigdy nie były archiwizowane ${ }^{5}$. Wydaje się zatem, że nazywanie autora Rzeczy dramatopisarzem byłoby trudne do uzasadnienia.

Jednakże dzieła Pereca - również te pozornie niezwiązane $\mathrm{z}$ teatrem - nie tylko wykazują olbrzymi potencjał dramatyczny, ale wpisują się również w nurt literatury performatywnej, która zmusza odbiorcę do uczestnictwa w rozgrywanym tekście. W jego utworach nic nie jest przypadkowe: ani postaci, ani cytaty, ani nawet szyk zdań. Wszystko jest elementem przemyślanej gry, którą autor podejmuje $\mathrm{z}$ wielkim rozmachem, żonglując konwencjami literackimi, prowokując dialog między dziełami (własnymi i cudzymi) oraz wplątując czytelnika w sam środek spiętrzonych chwytów, niuansów i symulacji. Pisanie Pereca można zatem uznać za czysty akt dramatyzacji, a on sam w pewnej mierze przyjmuje rolę reżysera, stawiając swoich odbiorców w pozycji nie tyle aktorów, co performerów „od(roz)grywających”6 jego teksty.

\section{Dialogowe eksperymenty}

Przynależność do OuLiPo znacząco wpłynęła na kształt wszystkich utworów Pereca, a zarazem pozwoliła mu stworzyć niepowtarzalny, jemu tylko właściwy styl pisania. Charakterystycznym elementem dla tej ma-

${ }^{4}$ Zob. G. Perec, Podwyżka, czyli jak, bez względu na warunki sanitarne, psychologiczne, klimatyczne, ekonomiczne i inne, uzyskać jak największe szanse, zwracając się do kierownika działu o podwyższenie płacy, przeł. D. Szuszkiewicz, Dialog, nr 7, lipiec 1985, s. 71-89; Por. idem, Teatr I, przeł. J Olczyk, Kraków 2010.

5 Jednym z nich jest wspomniany w rozmowie z Kaye Mortley Tagstimmen - utwór, który wykorzystuje możliwości ludzkiego głosu i próbuje opowiedzieć za pomocą przysłów, „co przydarzyło się człowiekowi od poranka do wieczora w języku wszystkich ludzi” (zob. G. Perec, K. Mortley, Robienie fikcji..., s. 179).

${ }_{6}^{6}$ Zob. A. Krajewska, dz. cyt., s. 214 i nast. 
niery jest wszechobecny dialog, objawiający się zarówno na płaszczyźnie wewnątrztekstowej, jak i na zewnątrz - w relacjach tekstu i odbiorcy, tekstu i jego autora oraz $\mathrm{w}$ powiązaniach intertekstualnych. Utwory francuskiego pisarza tworzą pewną organiczną całość, splątane kłącze, w którym wszystkie teksty łączą się, powielają i uzupełniają. Nierzadko dzieła, które zostały napisane wcześniej, stają się macierzą dla nowszych tekstów, a te z kolei reinterpretują i komentują wątki już podejmowane. Co ciekawe, taka koegzystencja nie ogranicza indywidualnej wyjątkowości i niezależności poszczególnych utworów. Można z powodzeniem czytać Gabinet kolekcjonera, nie znając Życia instrukcji obsługi, tak samo jak można zachwycić się Schowkiem Parmentier, nie odkrywając żadnego cytatu z powszechnie znanych na świecie dramatów lub analizować logiczne układy Podwyżki, nie wiedząc o istnieniu jej pierwowzoru. Problem polega na tym, że czytanie pomijające dialog odbiera twórczości Pereca to, co jest jej sensem - przyjemność uczestnictwa w grze, którą $\mathrm{u}$ podstaw zaplanował autor, a która wciąż samoistnie rozwija się w nieoczekiwanych kierunkach.

Rozgrywanie tekstu przybiera często kształt literalnie rozumianego układu planszy lub kryptogramu - staje się szyfrem, puzzlami, łamigłówką czy partią szachów. Może również odbywać się według ściśle określonych zasad, owego osławionego oulipiańskiego „dobrowolnego przymusu”, który miał spełniać dwie funkcje: „był obroną przed przypadkiem wpisanym w natchnienie i lekarstwem na pustkę w głowie"7. Rygor logiczny przyjmuje swą literacką formę w Podwyżce.

Utwór ten powstał na kanwie powieści, która w założeniu miała opisywać wszystkie warianty, jakie może rozważać pracownik ubiegający się o podwyżkę. W tekście $O$ sztuce oraz sposobach usidlenia kierownika działu $w$ celu upomnienia się o podwyżkę nie ma żadnych znaków interpunkcyjnych, a zapis przypomina (zapewne nieprzypadkowo) strumień świadomości. Tym bardziej zaskakiwać może sposób adaptacji tego utworu dla potrzeb radia. Perec nie wprowadził klasycznych bohaterów, którym mógłby przydzielić poszczególne kwestie. Ich rolę odgrywa sześć logicznych funkcji, według których porządkowane są poszczególne wypowiedzi: Propozycja (1), Alternatywa (2), Hipoteza pozytywna (3), Hipoteza negatywna (4), Wybór (5) i Wniosek (6). Każda z funkcji jest numerowana i według kolejności numeracji od jeden do sześć układane są kwestie:

1. Czatujesz na powrót Kierownika Działu.

2. Albo Kierownik zaraz wraca, albo długo nie wraca.

${ }^{7}$ M.P. Markowski, Perekreacja, Warszawa 2003, s. 117. 
3. Jeśli by wrócił zaraz, mógłbyś zapukać do jego pokoju i poczekać na odpowiedź.

4. Ale, gdyby długo nie wracał, najlepsze, co mógłbyś zrobić, to pójść do sąsiedniego pokoju, odwiedzić pannę Jolę, twoją koleżankę.

5. Przypuśćmy - a nie jest to rzadkością - że Kierownik Działu długo nie wraca.

6. W tym przypadku idziesz odwiedzić pannę Jolę

Gdy fabuła się rozwija, wypowiedzi wydłużają się, a kolejność numeracji ulega zaburzeniu, podkreślając iście Kafkowski absurd sytuacji. Utwór staje się odbiciem chaosu myślowego, uniwersalnym dialogiem uniwersalnego bohatera $\mathrm{z}$ samym sobą, który każdy człowiek choć raz przeprowadził, analizując dostępne opcje. Jest jednak również pastiszem logicznego myślenia, a ściśle numerowany porządek dialogu paradoksalnie odsłania karykaturalność sceny, sugerując zarazem, że wszystko jest względne, a ludzkimi wyborami rządzi przypadek. Radiowa Podwyżka pod względem wymowy nie różni się zatem znacząco od swego powieściowego pierwowzoru.

Autor Rzeczy w rozmowie z Kaye Mortley określa tworzenie fikcji jako swoistą grę autora z czytelnikiem:

W powieści staramy się grać tym, co prawdziwe, co nieprawdziwe, co myśleć o, lub co - po prostu, żeby utrzymać aurę zawieszenia w pewnym sensie - jak u Rolanda Barthesa. Coś jest suspendu - zawieszone - i jest to jak przebieg śnienia, wędrówki gdzie indziej w procesie fikcji. To, co najważniejsze w powieści, to jest, mógłbym rzec, to jest nie napisane. To jest coś, co pozostaje za słowami i co nigdy nie jest wypowiedziane ${ }^{9}$.

Ta zasada szczególnie mocno oddziałuje w utworach, które zbudowane są z cytatów: dramatycznym Schowku Parmentier i w minipowieści Gabinet kolekcjonera.

Jedyna sztuka w dorobku Pereca, napisana u schyłku jego życia, była przypuszczalnie dopiero początkiem jego teatralnych eksperymentów. Tytuł tomu - Teatr I - sugeruje, że pisarz zamierzał kontynuować wydawanie kolejnych „Teatrów”; niestety, nie zdążył. Ów niepowtarzalny status tym bardziej nadaje utworowi rys wyjątkowości, czyniąc ze Schowka reprezentacyjny przykład Perecowej wizji teatru i zarazem powierzając $\mathrm{mu}$ rolę dzieła podsumowującego literackie praktyki swojego autora. By jednak nie popaść w patetyczny nastrój, warto wspomnieć, że głównym tematem sztuki i pretekstem do snucia kolejnych myśli interpretacyjnych jest nie co innego jak pospolity, niemal każdemu znany ziemniak. Nie można jednak zakładać, że ów „bohater” jest zwyczajny.

8 G. Perec, Podwyżka..., s. 72.

${ }^{9}$ G. Perec, K. Mortley, Robienie fikcji..., s. 176. 
CHŁOPIEC: [...] Za mało mówi się o ziemniakach! Codziennie ze wzruszeniem powinno się myśleć o ziemniakach! To właśnie one nas żywią! Zawdzięczamy im wszystko!

STARA KOBIETA: Nie mógłby pan mówić o czymś innym?

CHŁOPIEC: Dlaczego miałbym mówić o czymś innym? Ziemniak to jest ciało stałe, a nie pusta gadanina, ściema, rojenia! Tego można dotknąć! To się obiera i to się je! Dzięki temu żyjemy! Nawet dzięki temu, że się tym zajmujemy!10.

To do ziemniaka właśnie odnoszą się przytaczane w utworze fragmenty wielu dzieł największych dramaturgów, między innymi Szekspira, Ionesco czy Becketta, przemieszane $\mathrm{z}$ cytatami z analiz, prognoz gospodarczych i danych statystycznych, okraszone dodatkowo elementami z różnych teatralnych konwencji11.

Sześcioro niby-bohaterów Schowka Parmentier - niewiele bardziej dookreślonych niż w Podwyżce - mówi zawsze cudzymi głosami, tak samo jak postaci pojawiające się w wydanym dwa lata wcześniej Gabinecie kolekcjonera, który jest najbardziej jaskrawym przykładem autoreferencjalnego powrotu autora do budowania światów z już powstałej materii literackiej. Michał Paweł Markowski nazywa takie działania „re-cytacją”, powtórnym cytowaniem, które nie gwarantuje dotarcia do istoty świata, ale zapewnia jedyną możliwą formę jego postrzegania12. Re-cytacja nie jest po prostu intertekstem. Polega na budowaniu kolejnych utworów na zasadzie wielopoziomowego dialogu fraz i myśli z innych tekstów, który ewoluuje w coraz to nowe formy, wchłaniając także zewnętrzne wpływy.

Mimo pozornych różnic gatunkowych Gabinet kolekcjonera i Schowek Parmentier są konstrukcyjnie podobne. Ten pierwszy jest wspomnieniem i przepisaniem Życia instrukcji obsługi, stanowi zatem przykład „wewnętrznej" (w odniesieniu do pisarstwa Pereca) cyrkulacji słowa, które w pewnej mierze przekształca się samo, tworząc coraz to nowe formy literackie. Drugi natomiast zachowuje i przetwarza frazy z utworów „na zewnątrz" przez umieszczanie ich w zaskakujących konfiguracjach oraz zmianę ich wydźwięku, ale nie pozbawia ich przy tym siły działania. Trywialność tematu i żonglowanie konwencjami jedynie wzmacnia ich dramatyczną ewolucję, stawiając w nowym kontekście fundamentalne pytania egzystencjalne, rozmywając granice fikcji i rzeczywistości, zacierając różnice między naśladowaniem a kreacją oraz wprowadzając już na wewnętrznym poziomie tekstu element wielopiętrowej gry.

\footnotetext{
10 http://www.teatr1.pointblue.com.pl/teatr.html (dostęp: 20.04.2017).

11 Por. tamże.

12 M.P. Markowski, dz. cyt., s. 151-152.
} 
Perec otwarcie w niej uczestniczy, nie sytuuje się na zewnątrz swoich utworów, ale przyjmuje postawę podobną do tej, którą reprezentował Tadeusz Kantor - zawsze w środku. Francuski autor traktował pisanie jako sposób życia. Bez pisania rzeczywistość nie mogła istnieć, ono ocalało jej okruchy. Dlatego oddzielenie jego samego od jego utworów nie jest możliwe. Dzieła autora Rzeczy są w pewnej mierze nim samym, jego wizją świata, którą próbuje udostępnić czytelnikom, wciągając ich w doświadczanie tekstów, a zarazem nie narzucając im bezpośrednio formy doświadczania.

Literatura jest nierozerwalnie związana z życiem, jest koniecznym przedłużeniem doświadczenia, jego oczywistym zwieńczeniem, jego nieodłącznym dopełnieniem. Każde doświadczenie otwiera się na literaturę, wszelka literatura otwiera się na doświadczenie, i droga, która wiedzie od jednego do drugiego - czy będzie to twórczość literacka czy lektura - ustanawia ową relację między częścią i całością [...], ową grę między ogólnym i szczegółowym, między odczuciem i rozumieniem, która tworzy tkankę naszej świadomości ${ }^{13}$.

Podjęcie gry Pereca jest zatem nie tylko przyjęciem roli, którą dyktuje autor-reżyser, ale również swoistym aktem współtworzenia uniwersum doświadczenia, które skupiają w sobie jego teksty. Czytelnik staje się katalizatorem performatywnego $\mathrm{w}$ swej istocie procesu wytwarzania światów.

\section{Miniatura $\dot{Z} y c i a^{14}$}

Najbardziej znaną powieścią Pereca, którą on sam określa jako dzieło życia, jest wspomniane już Życie instrukcja obsługi. O tym tekście, skonstruowanym według schematu wędrówki po wielopiętrowej kamienicy, po której czytelnik porusza się ruchem skoczka szachowego, napisano już wiele $^{15}$. Można jednak zaryzykować twierdzenie, że wiele $\mathrm{z}$ jego aspektów wciąż otwiera nowe pola interpretacyjne. Jednym $\mathrm{z}$ nich z pewnością są powiązania z Gabinetem kolekcjonera.

${ }^{13}$ G. Perec, L.G. Une aventure des années soixantes, Paris 1992, s. 88-89; [cyt. za:] M.P. Markowski, dz. cyt., s. 119.

14 Pojęcie zapożyczone od M.P. Markowskiego, zob. Perekreacja..., s. 151.

15 Zob. W. Brzozowski, Maszyna do produkcji arcydzieła. Instrukcja obsługi Życia instrukcji obstugi, „Literatura na Świecie” 1995, nr 11-12; H. Mathews, „Ta rzecz efemerycz$n a ”$, przeł. A. Sosnowski, „Literatura na Świecie” 1995, nr 11-12; G. Perec, C. Oriol-Boyer, H. Mathews, Co pobudza moje bajczarstwo? (rozmowa), przeł. A. Wasilewska, „Literatura na Świecie” 1995, nr 11-12; M.P. Markowski, dz. cyt.; A. Sosnowski, J. Gondowicz, J. Olczyk i in., Perec instrukcja obstugi, Kraków 2010. 
Komentując powstanie Gabinetu..., Perec stwierdza:

Nie chciałem całkowicie pożegnać się z Życiem instrukcją obsługi. To książka, nad którą pracowałem tak długo, że nie mogłem się od niej w ogóle uwolnić. Aby się uwolnić, pomyślałem, najprościej byłoby napisać krótkie opowiadanie, które nie miałoby żadnego bezpośredniego związku z Życiem, które jednak funkcjonowałoby dla mnie jako rodzaj szyfru. Życie byłoby w nim zakodowane, co pozwoliłoby mi po raz ostatni pracować nad podobnymi tematami ${ }^{16}$.

Wszystkie dzieła sztuki wspomniane w minipowieści są odzwierciedleniem listy wybranych elementów z Życia instrukcji obsługi. Markowski, próbując ułatwić deszyfrację, podaje podstawowe wskazówki, którymi może posłużyć się odbiorca:

Zasada była prosta: z każdego rozdziału Życia Perec wybrał jakiś element, który następnie uczynił tematem obrazu przedstawionego w książce, obrazu przedstawiającego gabinet kolekcjonera, sporządzonego na wzór siedemnastowiecznych „gabinetów”. Następnie obmyślił sensacyjną intrygę, która komplikowała lekturę i wywracała oczekiwania czytelnika. Całość miała mieć charakter fikcji o znamionach wszelkiego prawdopodobieństwa, wciągać czytelnika i udawać prawdę. [...] każdy z dziewięćdziesięciu dziewięciu obrazów obecnych w Gabinecie kolekcjonera wygenerowany został sztucznie z dziewięćdziesięciu dziewięciu rozdziałów wielkiej powieści. Klucz do tego chwytu Perec podsunął czytelnikowi sam, oznaczając numerami odpowiadającymi numerom rozdziałów obrazy wystawione na aukcji Raffke ${ }^{17}$.

W ten sposób opowieść o ekscentrycznym kolekcjonerze stała się palimpsestem nadpisanym na schemacie rozdziałów Życia... Znamienny jest fakt, że Perec postanowił zmienić medium, rozgrywając tekst na obrazie i za pomocą obrazu, który w dodatku dostępny jest odbiorcy jedynie w zacytowanym opisie. Narrator Gabinetu... prezentuje malowidła, które nie istnieją w rzeczywistości pozaliterackiej, mimo iż ich opisy - dzięki formie cytatu - skrupulatnie udają styl katalogów, a zarazem wykorzystuje prawdziwe nazwiska malarzy (Peter Paul Rubens, Jan Steen, Carel Fabritius, Jan Vermeer van Delft i inni) i parafrazuje autentyczne tytuły płócien, tworząc łudząco podobne nazwy nieistniejących dzieł, które mogłyby z powodzeniem zostać przypisane do szkoły konkretnego mistrza ${ }^{18}$.

Również tytułowy obraz przedstawiony w powiastce, ilekroć pojawia się $\mathrm{w}$ czyjejś wypowiedzi, nigdy nie jest opisywany bezpośrednio przez

16 A. Chauvin, H. Hartje, V. Larrie et I. Monk, Le „cahier des charges” d'Un cabinet d'amateur, [w:] L'Oleil d'abrod. Georges Perec et la peinture, „Cahier Georges Perec”, nr 6/1996; [cytat za:] M.P. Markowski, dz. cyt., s. 162.

${ }_{17}$ M.P. Markowski, dz. cyt, s. 163-164.

18 Por. tamże, s. 164-166. 
naocznego świadka ${ }^{19}$. Wszystkie dane zawarte w tekście są tylko cytatami z innych komentarzy. Nie ma żadnych przesłanek, które potwierdzałyby ich dokładność. Cytowany przez narratora fragment katalogowej noty opisuje obraz następująco:

Płótno przedstawia obszerny, prostokątny pokój bez widocznych drzwi i okien; trzy przedstawione ściany pokrywają bez reszty obrazy.

Na pierwszym planie, po lewej, przy małym, nakrytym koronkową serwetką gerydonie, na którym stoi kryształowa karafka i kieliszek na wysokiej nóżce, spoczywa na obitym ciemnozieloną pikowaną skórą fotelu mężczyzna ujęty en trois quarts, od tyłu wobec patrzącego. Jest to człowiek w podeszłym wieku, o gęstych siwych włosach i orlim nosie, na którym nosi okulary w stalowych oprawkach. Domyślić się można raczej, niż dostrzec naprawdę rysy jego twarzy: krostowaty policzek, krzaczaste wąsy, opadające znacznie poniżej górnej wargi, i kościsty, władczy podbródek. Odziany jest w szlafrok, którego szalowy kołnierz zdobi cienka czerwona lamówka. Wielki rudy pies o krótkiej sierści, częściowo zasłonięty ramieniem fotela i gerydonem, spoczywa, zdając się drzemać, u jego stóp. $\mathrm{Na}$ tym jednym płótnie zgromadzono ponad sto obrazów, oddanych $\mathrm{z}$ wiernością i skrupulatnością tak niezwykłą, iż można by dokładnie wszystkie je opisać. Samo wyliczenie tytułów i autorów byłoby jednak nie tylko nużące, lecz także przekroczyłoby dalece ramy niniejszej noty. Ograniczmy się do stwierdzenia, że wszelkie rodzaje oraz szkoły malarstwa europejskiego i młodej sztuki amerykańskiej - zarówno tematy religijne, jak i sceny rodzajowe, portrety i martwe natury, pejzaże oraz mariny etc. - są tu w podziwu godny sposób reprezentowane $[\ldots]^{20}$.

Język narracji w Gabinecie..., stylizowany na język katalogów i relacji z wystaw, recenzji dzieł sztuki oraz naszpikowany cytatami i pseudocytatami z tychże not wystawowych katalogów, recenzji i opracowań krytycznych, niejednokrotnie zmusza badacza do przytaczania obszernego fragmentu tekstu, ponieważ każde słowo w danym cytacie okazuje się ważne dla dalszych analiz i interpretacji. Ponadto Perec prowokuje piszącego o Gabinecie kolekcjonera do cytowania już zacytowanych tekstów. Już na wstępie badacz może zostać złapany w pułapkę wielopoziomowego charakteru tekstu, który nie tylko wciąga czytelnika do swojego wnętrza, ale potrafi go tam również zatrzymać. Niemniej, podejmując próbę zmierzenia się z tekstem Pereca, należy starać się, aby jego paranaukowy język nie zdominował własnych myśli i sposobu pisania, co bynajmniej nie jest łatwe.

Owo permanentne istnienie w cytacie odgrywa rolę czynnika scalającego autora i czytelnika z przeszłością objawiającą się poprzez literackie

19 Zob. tamże, s. 167.

${ }^{20}$ G. Perec, Gabinet kolekcjonera, przeł. W. Brzozowski, Kraków 2010, s. 13-14. Pełny tekst cytowanej noty s. 13-17. 
powroty do dzieł już napisanych (nie tylko przez Pereca, jak pokazuje konstrukcja Schowka Parmentier) oraz przez wrażenie ciągłości trwania w słowie - „ludzie bowiem są istotami cytującymi”21, stwierdza Odo Marquard. Możliwość cytowania można uznać zatem za substytut wieczności, który zapewnia cytującemu mityczne poczucie przynależności do pewnej wspólnoty, bycie częścią większej całości, która istniała wcześniej i będzie istnieć później. Możliwe, że niemal obsesyjne powtarzanie cytatów, tak często praktykowane przez francuskiego pisarza, miało kompensować niepewność własnej tożsamości i tłumić lęk przed utratą tego, co zostało od nowa wypracowane. Harry Mathews, pisząc o autorze Rzeczy, zauważa, że „w ponownych lekturach ulubionych książek znalazł Perec radość "współuczestnictwa, a nawet czegoś więcej: nareszcie odzyskanego pokrewieństwa«"22. Nieustanne autotematyczne powroty podtrzymuja zatem więź z tym, co bliskie, i zarazem zapraszają czytelnika, by dołączył do „rodziny” i podjął wyzwanie gry w życie (lub tu konkretnie: w Życie..., którego instrukcję obsługi sporządził autor).

Przytoczona wyżej deskrypcja portretu Raffkego jest nie tylko zacytowanym wyimkiem z bliżej nieokreślonego katalogu, ale zdradza także bezpośrednie konotacje z Życiem instrukcja obsługi, ponieważ stanowi parafrazę i kryptocytat podobnego opisu nigdy niepowstałego obrazu:

On także znalazłby się na swoim obrazie, w swoim pokoju, przy samym bez mała szczycie, po prawej, jak pajączek tkający troskliwie migotliwą sieć; stałby z paletą w dłoni obok swego płótna w zaplamionym farbami długim, szarym kitlu, z szyją okręconą fioletowym szalikiem.

On sam stałby tuż obok swojego, ukończonego już prawie obrazu i zajęty byłby malowaniem siebie - szkicowałby koniuszkiem pędzelka maleńką sylwetkę malarza w długim, szarym kitlu, z szyją okręconą fioletowym szalikiem i z paletą w dłoni, szkicującego miniaturową figurkę malarza, malującego raz jeszcze kurczącą się ku otchłani scenę, którą powtarzać chciałby w nieskończoność, tak jakby nie istniały granice wyznaczone przez rękę ni wzrok ${ }^{23}$.

Portret przedstawiony w Gabinecie kolekcjonera jest kolejnym podejściem do próby stworzenia dzieła zamykającego fragment rzeczywistości. Wydawać by się mogło, że tym razem ów projekt został zrealizowany. Obraz powstał, był główną atrakcją wystawy, ale nie istnieje żadna przesłanka w utworze Pereca, która sugerowałaby, że ktokolwiek z cytowanych bohaterów tam był i widział go na własne oczy. Brak bezpośrednie-

21 O. Marquard, Rozstanie z filozofia pierwszych zasad, przeł. K. Krzemieniowa, Warszawa 1994 , s. 110.

${ }^{22}$ H. Mathews, dz. cyt., s. 138.

23 Tenże, Życie instrukcja obstugi. Powieści, przeł. W. Brzozowski, Kraków 2009, s. 291. 
go opisu świadków stawia pod znakiem zapytania to, czym właściwie owo płótno było i czy w ogóle istniało. Tkwi ono w zawieszeniu między słowem a wyobrażeniem, istnieje w cudzysłowie, w opowieści, gdzie „[...] żadna $\mathrm{z}$ postaci nie przemawia wprost, lecz wypowiada się na piśmie, a jej słowa przytoczone są wyłącznie w formie cytatu"24. Skazanie obrazu na istnienie-nieistnienie paradoksalnie sprawiło, że stał się wiecznie obecny przez rozproszenie w cytacie, nieustanne od-twarzanie i re-kreację.

Istotne przy tym jest, że ślady tego-co-już-zapisane zostały zamknięte w obrazie, przepisane intertekstualnie - wydawać by się mogło - wykadrowane i zatrzymane w konkretnej chwili. Tymczasem autor Rzeczy przełamuje również tę właściwość poprzez ukazanie subtelnych różnic w kolejnych odsłonach odtwarzanych malowideł. Im głębiej sięga wzrok oglądającego, tym bardziej dostrzega upływ czasu objawiający się w przemianie. Takie ujęcie tematu może sugerować, że również sam Perec, pisząc Gabinet..., stał przed stworzonym przez siebie obrazem i spoglądał w głąb swojej pisarskiej przeszłości, ale to, co zobaczył, okazało się takie samo i inne jednocześnie. Gabinet kolekcjonera można zatem uznać za dobrze przemyślaną i artystycznie wycyzelowaną wariację na temat pojęcia mise-en-abîme, która realizuje się zarówno na poziomie re-cytującego tekstu, jak i w idei obrazu-głębi, który powtarza inne dzieła, wchłaniając zarazem przestrzeń i widza.

Ciekawy problem stanowią także malarskie cytaty z dzieł wielkich mistrzów znajdujące się na opisywanym płótnie. Imitując sformalizowany język autentycznych not katalogowych, narrator stawia się w pozycji bezstronnego sprawozdawcy, który odtwarza zaistniałe wydarzenia na podstawie różnych (w domyśle - wiarygodnych) źródeł. Nie inaczej dzieje się z graficzną metodą cytowania. Malarz, który stworzył tytułowy „Gabinet kolekcjonera"25, zastosował dość prostą metodę oszukania oglądających. Odwołał się do ogólnej przywary wszelkich miłośników "wielkiej” sztuki, którą można określić mianem "fałszywego znawstwa”. Wykorzystał na obrazach elementy powszechnie znane, charakterystyczne dla danej szkoły malarskiej lub konkretnego malarza, zbliżone stylem, kompozycją, tematem i - co najważniejsze - zwielokrotnione do granic możliwości percepcyjnych przeciętnego obserwatora, dzięki czemu oglądający stawał przed portretem nieistniejących obrazów zbudowanych z prawdziwych i realnie istniejących komponentów. Podobny zabieg Perec zastosował wobec czytelników: sparafrazował tytuły słynnych dzieł, dodał do nich równie słynne nazwiska lub wybrał mało znane obrazy i przypisał je fikcyjnym twórcom.

${ }^{24}$ M.P. Markowski, dz. cyt., s. 166.

25 Tytuł obrazu zapisuję w cudzysłowie, tytuł utworu kursywą. 
Ilość zastosowanych chwytów, aby wywieść w pole krytyków sztuki, nabywców obrazów i koniec końców samych czytelników, jest tak długa, że, paradoksalnie, właśnie to zwielokrotnienie kopii obrazów w obrazie, za którymi skrywała się skrupulatnie przez lata przygotowywana zemsta za inne oszustwa, których Raffke padł ofiarą, jak i opatrzenie ich fachowymi komentarzami sprawiło, że fałsz zyskał solidne podstawy, aby stać się prawdą, a falsyfikaty - oryginałami ${ }^{26}$.

Siła oddziaływania każdego z obrazów przedstawionych w ramach „Gabinetu kolekcjonera” została spotęgowana poprzez kolejne powtórzenia, które dodatkowo wzmocniły się dzięki fizycznie obecnej różnicy.

[Heinrich Kürz] wskazał [...] na doniosły wpływ estetycznych zabiegów związanych z „zasadą odbicia” na sytuację artysty, [...] przedstawiając w centrum obrazu tenże sam zamówiony obraz (jak gdyby Herman Raffke, spoglądając na swoją kolekcję, widział w niej płótno przedstawiające go w trakcie podziwiana własnej kolekcji; albo raczej jakby on sam, Heinrich Kürz, malując obraz przedstawiający kolekcję obrazów, widział w nim obraz, który właśnie maluje jednocześnie jego koniec i początek, obraz w obrazie i obraz o bra z u ), „dążący do nieskończoności efekt zwierciadła, w którym [...] oglądający i oglądany mieszają się wzajemnie w nieustającej konfrontacji"27. [wyróżn. E.W.-Cz.]

Autoreferencyjny charakter portretu piwowara prowokuje do zapytania, co tak naprawdę przedstawia "Gabinet kolekcjonera”. Chciałoby się rzec, że tematem obrazu jest on sam, jednakże, biorąc pod uwagę mnogość elementów przedstawionych na płótnie, okoliczności powstania oraz konsekwencje, które wywołało jego pokazanie (i zniknięcie), kwestia tematu przestaje być tak oczywista. Z pewnościa jest on rodzajem obrazu rekurencyjnego - wielokrotnie powtórzonym portretem samego siebie, ale nie można pominąć faktu, że subtelne różnice między poszczególnymi odwzorowaniami obrazów zamieszczonych na kolejnych wersjach płótna sugerują odrębność każdej z przedstawionych miniatur, która przegląda się $\mathrm{w}$ swoim odpowiedniku - niekoniecznie tym samym - w mniejszej skali.

Portret Raffkego może być traktowany jak odbicie twórczości Pereca. Tak jak jego utwory, każdy z obrazów ukazanych na kunstkamerze jest oryginalną częścią dzieła, które jest „jednostkowe”28 i ogólne zarazem.

26 J. Olczyk, W pogoni za szczególnym dreszczykiem, jaki daje stwarzanie pozorów; $<\mathrm{http}: / /$ www.lokatormedia.pl/w-pogoni-za-szczegolnym-dreszczykiem-jaki-daje-stwarzaniepozorow-jacek-olczyk/> (dostęp: 16.07.2015).

27 G. Perec, Gabinet kolekcjonera..., s. 24. Wyróżniony fragment otwarcie nawiązuje do przytoczonego wcześniej cytatu z Życia. Instrukcji obsługi.

28 Zob. G. Deleuze, Różnica i powtórzenie, przeł. B. Banasiak i K. Matuszewski, Warszawa 1997, s. 27. 
Przedstawia pewną uniwersalną całość, ideę kolekcji lub ideę pisarstwa, a zarazem ulega transgresji pod znakiem różnicy, objawiającej się nie tylko literalnie w postaci przemalowanych fragmentów obrazów składowych (prze-pisanych tekstów), ale przede wszystkim w złudnych próbach uchwycenia pierwszego spojrzenia z zewnątrz. Obecność fizycznych różnic między kolejnymi odsłonami płótna dodatkowo podkreśla niemożność odtworzenia i zastąpienia pierwotnego obrazu - ową niemożliwą tęsknotę, która nie pozwoliła Perecowi rozstać się z Życiem instrukcja obsługi i określiła kompletnie niepodobną formę powrotu w postaci Gabinetu kolekcjonera. Każda kolejna odsłona - obrazu czy tekstu - jest cytatem, który nie zastępuje, ale „kradnie” ${ }^{29}$, przekształca i potęguje cząstkę bytu tego, co już zostało zapisane, namalowane i zobaczone.

\section{Inscenizacje (poza)literackie}

Portret ukazany w Gabinecie kolekcjonera wielokrotnie - także w dosłownym rozumieniu - przekracza tradycyjnie pojmowane ramy obrazu, nieustannie przemieszczając swoje pole działania w kierunku teatralnej i preformatywnej interakcji z oglądającym. Cała, niewielka objętościowo powiastka Pereca jest imponującą literacką inscenizacją, w której aktorami są zarówno bohaterowie opowieści, autor, jak i czytelnicy - widzowie.

Pierwszym aktem owego przedziwnego spektaklu jest wystawa malarstwa w Pittsburghu w Pensylwanii, odbywająca się w ramach „serii imprez kulturalnych, zorganizowanych przez społeczność niemiecką miasta $\mathrm{z}$ okazji dwudziestopięciolecia panowania cesarza Wilhelma II", jak informuje narrator na samym początku historii. Tam właśnie pierwszy (i ostatni) raz pokazano „Gabinet kolekcjonera” i tam rozpoczęła się początkowo niewinna - gra $\mathrm{z}$ widzami wystawy, na których czekała „wspaniała niespodzianka":

[...] na płótnie swym artysta umieścił bowiem również i to dzieło [mowa o „Gabinecie kolekcjonera” - E.W.-Cz.], tak iż siedzący w swym gabinecie kolekcjoner ma przed oczyma, dokładnie na osi swego wzroku, wiszące na ścianie w głębi płótno, przedstawiające go w chwili, gdy podziwia własne zbiory, oraz wszystkie te obrazy na nowo pomniejszone - i tak dalej w pierwszym, drugim, trzecim odbiciu, aż wreszcie stają się one ledwie dostrzegalnymi śladami pędzla.

[...]

Aby uzyskać efekt większego jeszcze wyrafinowania, ekspozycję urządzono tak, aby przypominała możliwie jak najwierniej gabinet Hermana Raffkego ${ }^{30}$.

29 Por. tamże, s. 27.

${ }^{30}$ G. Perec, Gabinet kolekcjonera..., s. 17. 
Odwiedzający wystawę wnikliwie analizowali zawartość wizualnego wykazu kolekcji Raffkego, porównując coraz to mniejsze kopie sportretowanych obrazów. Znamienny dla mocy oddziaływania kunstkamery jest także sposób ukazania postaci kolekcjonera. Na portrecie widać było tylko jego plecy i część profilu, tak że możliwe było rozpoznanie tożsamości, jednak nie dało się dostrzec wyrazu jego oblicza. „Domyślić można się raczej, niż dostrzec naprawdę rysy jego twarzy"31.

Ktoś zwrócony do mnie tyłem strzeże swojej samotności, jego plecy są nieprzeniknioną barierą, granicą, której nie mogę pokonać. Pozostaje dla mnie enigmą: nie wiem, czy płacze, czy śmieje się, nie mogę się dowiedzieć, czy jego oczy są zamknięte, a jeżeli są otwarte - na co dokładnie kieruje się ich spojrzenie. Widzę świat p r z e d tym człowiekiem (jak na obrazach Caspara Davida Friedricha), lecz jego związek z tym światem pozostaje dla mnie niedostępny: nie widzę jego reakcji, wzruszenia czy obojętności, miłości ani nienawiści. Taki człowiek jest w ty m świecie, ale pozostaje dla mnie jego częścią, jakby się od niego niczym nie odróżniając; odczuwam więc przemożną pokusę, by traktować go tak samo, jak drewno okiennej ramy czy maszt przeciągającego obok statku ${ }^{32}$.

Perec jednoznacznie kieruje uwagę oglądającego na świat „przed”. Zainscenizowana przestrzeń gabinetu dodatkowo wzmacniała spojrzenie na obraz z perspektywy przedstawionego na nim kolekcjonera, pozwalała patrzącemu wejść w rolę bohatera portretu i utożsamić się z nim, czyniąc z niego uczestnika (lub twórcę) swoistego performansu.

Granice płótna zostały przekroczone przede wszystkim w głąb obrazu, właśnie w kierunku „środka z którego fascynuje”33 (Jacques Derrida sugeruje, by czasownik „fascynuje” potraktować jako nieprzechodni ${ }^{34}$, czyli - jak wyjaśnia tłumacz - by „»zawrócił« swe działanie na podmiot”35). Tam pojawia się pęknięcie, które pozwala przekroczyć przestrzeń do środka, ale jednocześnie ogranicza jej rozprzestrzenianie się na zewnątrz. Widz, stojąc w przestrzeni imitującej „Gabinet kolekcjonera”, odnosił wrażenie, że znajduje się na początku nieskończonego tunelu zwielokrotnionej rzeczywistości, przedstawionej na płótnie, gdzie każda kolejna kopia jest rodzajem portalu prowadzącego do wnętrza samego obrazu, a granica między oglądającym a oglądanym zaciera się. Nastąpiła swoista implozja świata widzialnego do wewnątrz dzieła, które sugerowało istnienie immanentnej, „fascynującej” nieskończoności. Wygląd

31 Tamże, s. 13.

32 T. Sławek, Byt bez twarzy, [w:] Twarz, red. A. Chojecki, S. Rosiek, „Punkt po Punkcie”, z. I, Gdańsk 2000, s. 20-21; wyróżnienia - T. Sławek.

33 J. Derrida, Prawda w malarstwie, przeł. M. Kwietniewska, Gdańsk 2003, s. 19.

34 Tamże, s. 19.

35 „[...] fascynujemy, czyli wytwarzamy fascynacje, które określają tylko nasz stan bycia ich źródłem" (zob. tamże, przypis s. 464). 
wystawy dodatkowo prowokował patrzącego do wejścia w wewnętrzną przestrzeń dzieła, do próby stania się jego częścią. Stworzona iluzja sprawiła, że patrzący popadali w rodzaj transu spowodowanego wielokrotnym powtórzeniem i dążyli do jak najbliższego, fizycznego kontaktu z płótnem.

Kolejnym aktem osobliwego spektaklu była śmierć Raffkego, a szczególnie zorganizowany według zawartych w jego testamencie wytycznych niezwykły pogrzeb:

Ciało, spreparowane przez najwybitniejszego wówczas wypychacza zwierząt, [...] odziano w szary szlafrok z czerwoną lamówką, w którym Raffke pozował do obrazu Kürza, i posadzono w fotelu uwiecznionym na obrazie. Następnie fotel wraz ze zwłokami przeniesiono do grobowca, odtwarzającego wiernie, choć w znacznie pomniejszonej skali, gabinet, w którym Raffke zawiesił ulubione dzieła. Wielka kompozycja Heinricha Kürza zajmowała całą ścianę w głębi. Nieboszczyka umieszczono naprzeciw obrazu w identycznej pozycji jak na płótnie. [...] Na końcu zamurowano grobowiec ${ }^{36}$.

Nieco makabryczna inscenizacja pozornie kończy historię tytułowego obrazu i jego właściciela, jednakże w istocie jest ona wstępem do prawdziwego punktu kulminacyjnego opowieści - licytacji kolekcji zmarłego piwowara, zakończonej „rozpoznaniem” prawdziwej natury sprzedanych obrazów, będącym formą Arystotelesowskiej anagnorisis ${ }^{37}$. Wydawać by się mogło, że fałszywość kolekcji Raffkego została jednoznacznie potwierdzona przez jego spadkobierców. Więcej - kolekcja ta w tradycyjnie pojmowanej formie właściwie nie istniała, ponieważ jej powstawanie zaprzeczało idei kolekcjonerstwa. Jednak jeśli wziąć pod uwagę sam tytułowy obraz, wiele z powyższych stwierdzeń należy postawić pod znakiem zapytania.

Sportretowany Raffke patrzy na „prawdziwe” dzieła, które wiszą na ścianach jego gabinetu. Kolekcjoner pozujący do obrazu znajdował się na zewnątrz i patrzył tylko na wyobrażenie kolekcji, jej symulację. To, co powstawało na płótnie, było jego wymarzoną kolekcją, której możliwości zgromadzenia go pozbawiono, zadrwiono z niego. Patrzył na swoje pragnienia, ale co rzeczywiście widział? Oglądający, tak jak bohater obrazu, patrzy na to, czego sam pożąda, ale nie może tego mieć. Nie zastanawia się nad tym, czy to, co widzi, jest prawdziwe, czy też mami go jego własnym wyobrażeniem autentyczności oglądanych obrazów, które mogły nie istnieć (i nie istniały) poza płótnem, na którym je przedstawiono. Rozpatrywanie ich statusu w kategoriach prawdy i fałszu jest kwestią dys-

${ }^{36}$ G. Perec, Gabinet kolekcjonera..., s. 26.

37 Bohaterowie spektaklu - świadomie lub nieświadomie w nim uczestniczący - zyskali wiedzę, której wcześniej nie mieli. 
kusyjną, ponieważ są przedstawieniem przedstawienia, Barthesowską „kopią (namalowanej) kopii rzeczywistości”, zwielokrotnioną fikcją.

Postać kolekcjonera stanowi rodzaj zwierciadła, w którym w pewnej mierze odbija się twarz samego Pereca. W historii kolekcji Raffkego, podobnie jak w ulubionych zbiorach autora Rzeczy, główną rolę odgrywały wrażenia, zachwyty i rozczarowania wszystkich tych, których zafascynował jego portret. Również tych oglądających „Gabinet...” przez pryzmat czytanej opowieści.

Opisana w Gabinecie kolekcjonera inscenizacja obrazu nawiązuje do parateatralnych widowisk nazywanych „żywymi obrazami” (tableaux vivantes). Tradycja aranżowania scen upozowanych na wzór dzieł sztuki oraz próby wizualizacji fragmentów literackich sięga czasów średniowiecza, jednak największą popularność zdobyła w XVIII i XIX wieku. „Żywe obrazy" spełniały przede wszystkim rolę estetyczną. Miały cieszyć oko i „przyjemnie oddziaływać na zmysły” - jak pisze Małgorzata Komza w monografii poświęconej temu tematowi ${ }^{38}$. Istotny jednakże był również fakt, że inscenizacje tworzono z udziałem żywych „aktorów”, co pozwalało na przeniesienie abstrakcyjnej ontologii sztuki na grunt rzeczywisty było autentycznym Berleantowskim wcieleniem ${ }^{39}$, pozostając zarazem gloryfikacją mimetyzmu (im bardziej scena przypominała pierwowzór, tym większy zachwyt budziła). Owo „wcielanie się” zdradza rodowód teatralny. „Przez swe genetyczne związki z malarstwem żywe obrazy mogły być odbierane jak wystawione publicznie dzieło sztuk plastycznych. Oglądane były jednak w tym samym czasie, w grupie, a więc recepcja przebiegała niczym $\mathrm{w}$ teatrze" 40 . Iluzjonistyczny charakter inscenizacji - podobnie jak w przypadku obrazu z Gabinetu kolekcjonera - silnie oddziaływał na widzów, budząc ciekawość zarówno z powodu swych imitacyjnych zdolności, jak i ulotności przedstawienia, które za każdym razem stawało się nowym obrazem. „W reakcjach uczestników można było odnaleźć zarówno coś z emocji widzów oglądających wystawę, jak i zrytualizowanych zachowań widzów teatralnych"41 - podkreśla Komza.

Opisane zabiegi inscenizacyjne wokół obrazu wzmacniają efekt dramatycznego i performatywnego przemieszczenia. Tworząc wierną imitację przedstawionej na obrazie przestrzeni, połączono dwa światy: świat przedstawiony i świat pozaobrazowy. Użycie określenia „rzeczywisty” wydaje się tu bezcelowe, ponieważ zarówno odtworzenie wyglądu gabine-

38 Zob. M. Komza, Żywe obrazy. Między scena, obrazem i książka, Wrocław 1995, s. 23.

39 Zob. A. Berleant, Prze-myśleć estetykę. Niepokorne eseje o estetyce $i$ sztuce, przeł. M. Korusiewicz, T. Markiewicz, red. K. Wilkoszewska, Kraków 2007, s. 110-120.

40 Zob. tamże, s. 272.

41 Zob. tamże. 
tu Raffkego na wystawie, jak i aranżacja miejsca wiecznego spoczynku piwowara tak znacznie upodobniły sferę zewnętrzną do wnętrza obrazu, że stała się ona integralną częścią płótna, rozciągając obszar jego oddziaływania daleko poza ramy malowidła. Przestrzeń inscenizowana stała się widzialnym symulakrem rzeczywistości obrazu, a sam „Gabinet kolekcjonera” symulował istnienie rzeczywistości wyobrażonej przez Raffkego i sugerowanej w ten sposób oglądającym obraz. Widz odwiedzający wystawę wkraczał - $\mathrm{z}$ założenia nieświadomie - $\mathrm{w}$ sferę zawieszonej referencyjności ${ }^{42}$, wytworzoną przez obszar nawarstwionych symulacji, gdzie fikcja obrazu wydawała się bardziej prawdziwa i wiarygodna niż prawda. Portret piwowara otoczonego wyobrażeniem swojej kolekcji zastapił samą kolekcję, nie pozwalając widzowi na wątpliwości odnoszące się do jej istnienia.

\section{Kawałek układanki}

Dramatyczny potencjał utworów Pereca ujawnia się także w próbach kontynuacji jego eksperymentów - owego „pisania na nowo”, które jest zarazem powtórzeniem i nowym początkiem. Jednym z najciekawszych projektów nawiązujących do pisarstwa autora Pamiętam że... jest stworzone przez Jerzego Franczaka i Piotra „Pio” Kalińskiego Wyczerpanie - tekst będący rezultatem powtórzonego po czterdziestu latach doświadczenia Pereca, którego owocem była opublikowana w 1975 roku Próba wyczerpania pewnego miejsca paryskiego (Tentative d'épuisement d'un lieu parisien). Rok wcześniej pisarz zasiadł w kawiarni przy placu Saint-Sulpice w Paryżu i zaczął zapisywać to, co widzi w danym momencie bez fabuły, bez narracji, próbując „wyczerpać” wszystko, co był w stanie zarejestrować w czasie teraźniejszym danego miejsca. Trudno oprzeć się wrażeniu, że działanie Pereca miało charakter literacko-autotelicznego performansu, w którym uczestniczyli wszyscy i wszystko w zasięgu wzroku autora. Cały proces rejestracji wrażeń trwał trzy dni i był próbą spostrzegawczości i wytrzymałości dla samego Pereca, który mimo wszystko nie potrafił patrzeć jedynie $\mathrm{z}$ zewnątrz. Ernst van Alphen zauważa, że w pewnych momentach przebija się wewnętrzny świat lęków i wspomnień, który bynajmniej nie fałszuje spojrzenia, ale je rozszerza ${ }^{43}$. Próba wyczerpania... pokazuje Pereca jako autora i aktora, który usiłuje prawdziwe doświadczyć, by móc pisać doświadczeniem.

Franczak i Kaliński próbują podążyć jego śladami i sprawdzić, czy rejestrowanie świata nadal może stanowić podstawę tworzenia. „Chodziło

42 Zob. J. Baudrillard, Symulakry i symulacja, przeł. S. Królak, Warszawa 2005, s. 7.

43 Zob. E. van Alphen, Spis rzeczy: wsparcie i blokada pamięci, przeł. K. Bojarska, <http://pismowidok.org/index.php/one/article/view/29/31> (dostęp: 21.04.2017). 
o to, żeby wykorzystać utajony potencjał konceptu stojącego za Tentative d'épuisement. Nie spastiszować czy sparodiować, tylko całkiem serio ponowić" 44 - podkreśla Franczak. Zastanawia się ponadto nad charakterem podjętego zadania. „Czy to jeszcze powtórzenie, czy już oryginalny pomysł? A może ani jedno, ani drugie, może to, co oryginalne i najbardziej własne, ujawnia się w powtórzeniu? Bo każde powtórzenie wprawia w ruch grę różnic, dzięki niemu ujawnia się odmienność: epoki, kontekstu instytucjonalnego, ale przede wszystkim postawy artysty. To dlatego było dla mnie od początku jasne, że powstanie coś odmiennego od tej książeczki sprzed czterech dekad. Samego Pereca dosięga to w niewielkim stopniu. Zresztą uważam, że każda przeróbka - nawet parodystyczna - wzmacnia pierwowzór"45. Zaskakuje fakt, że tym razem wynikiem obserwacji placu nie był jedynie zapis, ale również seria szkiców, które oddawały wizualny wygląd miejsca wybranego przez Pereca. Autorzy Wyczerpania - świadomie bądź nie - powtórzyli także jego gest przepisania tekstu-wspomnienia na obraz, tak jak on sam uczynił to w Gabinecie kolekcjonera.

Życie autora Kondotiera było pisaniem, które rozgrywało się zarówno literalnie - przez opisywanie tego, co zastane w danej chwili, jak i pozaczasowo - przez nieustanne powroty i zatrzymania w wewnętrznym obiegu słowa $\mathrm{w}$ jego utworach. Jeden $\mathrm{z}$ twórców Wyczerpania podsumowuje swoją wypowiedź wyznaniem, że ostatnie fragmenty książki są zlepkiem jego własnych obserwacji i zapisków Pereca, swoistym powrotem i pogodzeniem się z jego wizją ${ }^{46}$. Czy to oznacza, że słowa autora $\dot{Z} y c i a$ instrukcji obstugi znów zatoczyły koło i nowa książka jest kontynuacją dialogu, w którym pisarz staje się upragnionym kawałkiem układanki? Można zaryzykować odpowiedź twierdzącą, skoro jego metody pisania wciąż budzą zainteresowanie, nadal nie zostały wyczerpane i pozostają „płodne”, pozwalając na powstawanie pełnowartościowych utworów, które w dodatku wiążą przeszłość z teraźniejszością.

\section{BIBLIOGRAFIA}

Alphen E. van, Spis rzeczy: wsparcie i blokada pamięci, przeł. K. Bojarska, <http://pis mowidok.org/index.php/one/article/view/29/31> (dostęp: 21.04.2017).

Baudrillard J., Symulakry i symulacja, przeł. S. Królak, Warszawa 2005.

${ }^{4}$ Wyczerpujacy eksperyment. Jerzy Franczak i PIO w rozmowie z Michałem Sowińskim i Katarzyną Trzeciak, <http://www.ha.art.pl/projekty/rozmowy/4911-wyczerpujacy-ek speryment-jerzy-franczak-i-pio-w-rozmowie-z-michalem-sowinskim-i-katarzyna-trzeciak. html> (dostęp: 21.04.2017).

45 Tamże, (dostęp: 21.04.2017).

46 Tamże, (dostęp: 21.04.2017). 
Berleant A., Prze-myśleć estetykę. Niepokorne eseje o estetyce i sztuce, przeł. M. Korusiewicz, T. Markiewicz, red. K. Wilkoszewska, Kraków 2007.

Brzozowski W., Maszyna do produkcji arcydzieła. Instrukcja obstugi Życia instrukcji obstugi, „Literatura na Świecie” 1995, nr 11-12.

Chauvin A., Hartje H., Larrie V., Monk I., Le „cahier des charges” d'Un cabinet d'amateur, [w:] L'Oleil d'abrod. Georges Perec et la peinture, „Cahier Georges Perec" 1996, nr 6.

Deleuze G., Różnica i powtórzenie, przeł. B. Banasiak i K. Matuszewski, Warszawa 1997.

Derrida J., Prawda w malarstwie, przeł. M. Kwietniewska, Gdańsk 2003.

Komza M., Żywe obrazy. Między scena, obrazem i książka, Wrocław 1995.

Krajewska A., Dramatyczna teoria literatury. Zarys problematyki, Poznań 2009.

Markowski M.P., Perekreacja, Warszawa 2003.

Marquard O., Rozstanie z filozofia pierwszych zasad, przeł. K. Krzemieniowa, Warszawa 1994.

Mathews H., „Ta rzecz efemeryczna”, przeł. A. Sosnowski, „Literatura na Świecie” 1995, nr 11-12.

Olczyk J., W pogoni za szczególnym dreszczykiem, jaki daje stwarzanie pozorów; <http://www.lokatormedia.pl/w-pogoni-za-szczegolnym-dreszczykiem-jaki-daje-st warzanie-pozorow-jacek-olczyk/> (dostęp: 16.07.2015).

Perec G., Gabinet kolekcjonera, przeł. W. Brzozowski, Kraków 2010.

Perec G., L.G. Une aventure des années soixantes, Paris 1992.

Perec G., Podwyżka, czyli jak, bez względu na warunki sanitarne, psychologiczne, klimatyczne, ekonomiczne i inne, uzyskać jak największe szanse, zwracajac się do kierownika działu o podwyższenie płacy, przeł. D. Szuszkiewicz, „Dialog” 1985, nr 7, lipiec.

Perec G., Teatr I, przeł. J Olczyk, Kraków 2010.

Perec G., Życie instrukcja obstugi. Powieści, przeł. W. Brzozowski, Kraków 2009.

Perec G., Mortley K., Robienie fikcji (rozmowa), przeł. A. Sosnowski, „Literatura na Świecie" 1995, nr 11-12.

Perec G., Oriol-Boyer C., Mathews H., Co pobudza moje bajczarstwo? (rozmowa), przeł. A. Wasilewska, „Literatura na Świecie” 1995, nr 11-12.

Sławek T., Byt bez twarzy, [w:] Twarz, red. A. Chojecki, S. Rosiek, „Punkt po Punkcie” 2000 , z. I.

Sosnowski A., Gondowicz J., Olczyk J.i in., Perec instrukcja obstugi, Kraków 2010.

<http://www.teatr1.pointblue.com.pl/teatr.html> (dostęp: 20.04.2017).

Wasilewska A., Od ttumacza, [w:] I. Calvino, Jeśli zimowa nocą podróżny..., Warszawa 1989.

Wasilewska A., Oulipo, czyli recepta na życie bez końca; <http://www.lokatormedia.pl /oulipo-nie-konczy-nawet-smierc-anna-wasilewska/> (dostęp: 21.04.2017).

Wyczerpujacy eksperyment. Jerzy Franczak i PIO w rozmowie z Michałem Sowińskim i Katarzyną Trzeciak. <http://www.ha.art.pl/projekty/rozmowy/4911-wyczerpuja cy-eksperyment-jerzy-franczak-i-pio-w-rozmowie-z-michalem-sowinskim-i-katarz yna-trzeciak.html> (dostęp: 21.04.2017). 